\title{
Purification and characterization of laccase from Coriolopsis floccosa MTCC-1177 and its use in the selective oxidation of aromatic methyl group to aldehyde without mediators
}

\author{
P K CHAURASIA, A YADAV, R S S YADAV* and S YADAVA \\ Department of Chemistry, DDU Gorakhpur University, Gorakhpur 273 009, India \\ e-mail: rssy_chemistry@ rediffmail.com
}

MS received 15 December 2012; revised 24 August 2013; accepted 26 August 2013

\begin{abstract}
A laccase from the culture filtrate of white rot fungus Coriolopsis floccosa MTCC-1177 has been purified to homogeneity. The method involved concentration of the culture filtrate by ammonium sulphate precipitation and an anion exchange chromatography on diethylaminoethyl (DEAE) cellulose. Sodium dodecyl sulphate polyacrylamide gel electrophoresis (SDS-PAGE) as well as native polyacrylamide gel electrophoresis (native-PAGE) produced single protein bands indicating that the enzyme preparation was pure. Molecular mass of the enzyme determined from SDS-PAGE analysis was $64 \mathrm{kDa}$. Using 2,6-dimethoxyphenol (DMP), 2,2'[Azino-bis-(3-ethylbonzthiazoline-6-sulphonic acid (ABTS) diammonium salt and 4-hydroxy-3,5-dimethoxy benzaldehyde azine (syringaldazine) as the substrates, the $K_{\mathrm{m}}, k_{\text {cat }}$ and $k_{\text {cat }} / K_{\mathrm{m}}$ values of the laccase were found to be $112.5 \mu \mathrm{M}, 5.16 \mathrm{~s}^{-1}, 4.60 \times 10^{4} \mathrm{M}^{-1} \mathrm{~s}^{-1}, 58 \mu \mathrm{M}, 5.16 \mathrm{~s}^{-1}, 8.90 \times 10^{4} \mathrm{M}^{-1} \mathrm{~s}^{-1}$ and $100 \mu \mathrm{M}, 5.16 \mathrm{~s}^{-1}$, $5.16 \times 10^{4} \mathrm{M}^{-1} \mathrm{~s}^{-1}$, respectively. The $\mathrm{pH}$ and temperature optima were $5.0^{\circ} \mathrm{C}$ and $40^{\circ} \mathrm{C}$, respectively. Activation energy for thermal denaturation of the enzyme was $36.6 \mathrm{~kJ} / \mathrm{mol} / \mathrm{K}$. The enzyme was most stable at $\mathrm{pH} 4.0$ when exposed for $1 \mathrm{~h}$. The purified laccase has yellow colour and does not show absorption band around $610 \mathrm{~nm}$ found in blue laccases. The enzyme transforms toluene, 3-nitrotoluene and 4-chlorotoluene to benzaldehyde, 3-nitrobenzaldehyde and 4-chlorobenzaldehyde, respectively, in the absence of electron transfer mediators.
\end{abstract}

Keywords. Cu enzymes; yellow laccases; lignolytic enzymes; Coriolopsis floccosa; 2,6- dimethoxyphenol; white rot fungus.

\section{Introduction}

Laccase (benzenediol: oxygen oxidoreductase; EC 1.10.3.2) is a polyphenol oxidase, which belongs to the super family of multicopper oxidases ${ }^{1,2}$ and catalyses $^{3-5}$ the four-electron reduction of molecular oxygen to water. Laccases are dimeric or tetrameric glycoproteins. To perform their catalytic function, laccases depend on $\mathrm{Cu}$ atoms that are distributed at the three different copper centres viz. type-1 or blue copper centre, type- 2 or normal copper centre and type- 3 or coupled binuclear copper centres, differing in their characteristic electronic paramagnetic resonance (EPR) signals. ${ }^{6}$ The organic substrate is oxidized by one electron at the active site of the laccase generating a reaction radical which further reacts non-enzymatically. The electron is received at type $1 \mathrm{Cu}$ and is shuttled to the trinuclear cluster where oxygen is reduced to water.

*For correspondence
Ortho and para diphenols, aminophenols, polyphenols, polyamines, lignins, and arylamines and some of the inorganic ions are the substrates for laccases. ${ }^{7-9}$ The biotechnological importance of laccases has increased after the discovery that oxidizable reaction substrate range could be further extended in the presence of small readily oxidizable molecules called mediators. ${ }^{10,11}$ During the last two decades, laccases have turned out to be the most promising enzymes for industrial uses $^{8,9}$ having applications in food, pulps, paper, textile, and cosmetics industries and in synthetic organic chemistry. ${ }^{12-15}$

Laccases purified from different sources exhibit different properties and are suitable for different applications. Thus, there is scientific need to search for new sources of laccases with different properties suitable for different applications. Keeping these points in view, the authors have initiated studies on purification and characterization of laccases from different fungal sources so that suitable laccases for different applications could be identified. Coriolopsis floccosa MTCC-1177 is a white rot fungus isolated from logs of Shorea robusta. ${ }^{16}$ Being a white rot fungus, it is expected to secrete lignolytic 
enzymes, hence it was screened for laccase secretion. There are reports ${ }^{17,18}$ that blue laccase-secreting fungal strains secrete yellow laccases in the presence of culture media containing natural lignin-containing substrates. ${ }^{8-21}$ Though blue laccases have been extensively investigated, ${ }^{4}$ studies on yellow laccases are rare. ${ }^{17,18}$ Moreover, blue laccases oxidize aromatic methyl group selectively to aldehyde group in the presence of mediator molecules, ${ }^{22-24}$ whereas some of the yellow laccases perform the same reaction in absence of mediator molecules. This communication reports a yellow laccase of $C$. floccosa which selectively transforms methyl group to aldehyde group in the absence of mediator molecules.

\section{Experimental}

\subsection{Materials}

4-Hydroxy-3,5-dimethoxybenzaldehyde azine (syringaldazine), 4-chlorotoluene and diethylaminoethyl (DEAE) cellulose were obtained from Sigma Chemical Company, St. Louis (USA). 2,2'-Azino-bis (3ethylbenzthiazoline-6-sulphonic acid) diammonium salt (ABTS) and 2,6-dimethoxy phenol (DMP) were obtained from Fluka, Chemi New Ulm (Switzerland). All other chemicals used in these investigations were either from Himedia Laboratory Ltd., Mumbai (India) or from E Merck Ltd., Mumbai (India) and were used without further purification. Chemicals used in gel electrophoresis of the protein samples were obtained from Bangalore Genei Pvt. Ltd., Bangalore (India).

\subsection{Fungal strain and its growth}

The fungal strain was procured from the Microbial Type Culture Collection Centre and Gene Bank, Institute of Microbial Technology, Chandigarh (India) and maintained on agar slant as reported in MTCC Catalogue of strains-2000. ${ }^{16}$ Growth medium for the fungal strain $C$. floccosa MTCC-1177 consisted of malt extract $20.0 \mathrm{~g}$, and agar $20.0 \mathrm{~g}$ in $1.0 \mathrm{~L}$ Milli-Q water. The $\mathrm{pH}$ of the medium was adjusted to 6.5 .

In order to detect extracellular secretion of the laccase by $C$. floccosa MTCC-1177, the liquid culture growth medium reported by Coll et al. ${ }^{25}$ was used. This medium consisted of glucose $10.0 \mathrm{~g}$, asparagine $1.0 \mathrm{~g}$, yeast extract $0.5 \mathrm{~g}, \mathrm{MgSO}_{4} .7 \mathrm{H}_{2} \mathrm{O}$ and $\mathrm{FeSO}_{4} .7 \mathrm{H}_{2} \mathrm{O}$, $0.01 \mathrm{~g}$ in $1.0 \mathrm{~L}$ of Milli-Q water. The above liquid culture growth medium containing natural lignin substrates such as coir dust, corn cob, wheat straw, saw dust and bagasse particles was separately prepared by adding
$0.5 \mathrm{~g}$ of one of the natural lignin substrates to $25 \mathrm{~mL}$ of growth medium in $100 \mathrm{~mL}$ culture flasks which were sterilized. Sterilized growth media were inoculated with small pieces of mycelia $(0.5 \mathrm{~cm} \times 0.5 \mathrm{~cm})$ under aseptic condition and the fungal cultures were grown under stationary culture conditions at $25^{\circ} \mathrm{C}$ in a biological oxygen demand (BOD) incubator. In order to monitor the production of laccase in the liquid culture medium, $0.5 \mathrm{~mL}$ aliquots of the growth medium were withdrawn at regular intervals of $24 \mathrm{~h}$. and filtered through sterilized Millipore filter $0.22 \mu \mathrm{m}$. The filtered extract was analysed for activity of laccase using DMP as the substrate by the method ${ }^{25}$ provided in the assay section. Extracellular secretion of laccase in the liquid culture medium by $C$. floccosa MTCC-1177 was determined by plotting the enzyme Unit $/ \mathrm{mL}$ of the growth medium against the number of days after inoculation of the fungal mycelia. Each point on the curve is an average of three measurements. Growth medium for the control experiment has the same composition except that no natural lignolytic substrate has been added. In order to optimize the conditions for maximum secretion of the laccase by $C$. floccosa MTCC-1177 in the liquid culture medium, the amount of the best inducer, bagasse particles, was varied from $80-1000 \mathrm{mg}$ in $25 \mathrm{~mL}$ of the growth medium. The amount of the inducer in the growth medium which gave the maximum height of enzyme activity peak was taken as optimal amount of the inducer.

\subsection{Enzyme assay}

$1.0 \mathrm{~mL}$ of the assay solution for DMP as the substrate ${ }^{25}$ contained $1.0 \mathrm{mM}$ DMP in $50 \mathrm{mM}$ sodium malonate buffer $\mathrm{pH} 4.5$ at $37^{\circ} \mathrm{C}$, while ABTS as substrate ${ }^{26}$ contained $0.5 \mathrm{mM}$ ABTS in $0.1 \mathrm{M}$ sodium acetate buffer pH 5.0 at $25^{\circ} \mathrm{C}$ and syringaldazine as the substrate ${ }^{27}$ contained $0.1 \mathrm{mM}$ syringaldazine in $50 \mathrm{mM}$ sodium phosphate buffer $\mathrm{pH} 6.0$ at $50^{\circ} \mathrm{C}$. In case of DMP, the reaction was monitored by measuring absorbance change at $\lambda=468 \mathrm{~nm}$ and using molar extinction coefficient value of $49.6 \mathrm{mM}^{-1} \mathrm{~cm}^{-1} .{ }^{25}$ In case of ABTS, the reaction was monitored by measuring absorbance change at $\lambda=420 \mathrm{~nm}$ and using molar extinction coefficient value of $36.0 \mathrm{mM}^{-1} \mathrm{~cm}^{-1}{ }^{26}$ In case of syringaldazine, the reaction was monitored by measuring absorbance change at $\lambda=530 \mathrm{~nm}$ and using molar extinction coefficient value of $64.0 \mathrm{mM}^{-1} \mathrm{~cm}^{-1} .^{27}$ UV/Vis spectrophotometer Hitachi (Japan) model U2900 fitted with electronic temperature control unit was used for absorbance measurement. The least count of absorbance measurement was 0.001 absorbance unit. 
One enzyme unit produced $1 \mu \mathrm{mol}$ of the product per minute under the specified assay conditions.

\subsection{Purification of laccase}

For purification of laccase, C. floccosa MTCC-1177 was grown in $10100 \mathrm{~mL}$ culture flasks, each containing $25 \mathrm{~mL}$ sterilized growth medium consisting optimal amount $200 \mathrm{mg}$ of the inducer, bagasse particles, under stationary culture condition in a BOD incubator at $25^{\circ} \mathrm{C}$. Maximum activity of laccase appeared on the 7 th day of inoculation of the fungal mycelia. On the 7th day, all the cultures in the 10 flasks were pooled together, mycelia were removed by filtration through four layers of cheese cloth. The culture filtrate was saturated up to $25 \%$ with ammonium sulphate and centrifuged using refrigerated Sigma (Germany) model $3 \mathrm{~K}-30$ at $14000 \mathrm{rpm}$ for $20 \mathrm{~min}$ at $4^{\circ} \mathrm{C}$. The precipitate was discarded and the supernatant was saturated up to $90 \%$ by further addition of ammonium sulphate. The resulting suspension was centrifuged by repeating the process of centrifugation and the supernatant was discarded. The precipitate was dissolved in $100 \mathrm{mM}$ sodium acetate buffer $\mathrm{pH} 4.5$ and dialysed against $10 \mathrm{mM}$ sodium-acetate buffer $\mathrm{pH} 4.5$ in volume ratio 1:1000 with three changes at the intervals of $8 \mathrm{~h}$. The dialysed enzyme sample $25 \mathrm{~mL}$ containing $1.8 \mathrm{mg} / \mathrm{mL}$ protein was loaded on to the DEAE column (size $0.75 \mathrm{~cm} \times 19.0 \mathrm{~cm}$ ), which was pre-equilibrated with $10 \mathrm{mM}$ sodium acetate/acetic acid buffer ( $\mathrm{pH} 4.5)$ and the flow rate was $6 \mathrm{~mL} / \mathrm{h}$. The column was washed with $100 \mathrm{~mL}$ of the same buffer. The enzyme was eluted by applying linear gradient of $\mathrm{NaCl}$ in the range of $0.0-1.0 \mathrm{M}(50 \mathrm{~mL}$ buffer $+50 \mathrm{~mL}$ buffer with $1.0 \mathrm{M}$ $\mathrm{NaCl}$ ). Fractions of $5.0 \mathrm{~mL}$ size were collected and analysed for laccase activity. ${ }^{25}$ Protein estimation was done by Lowry method. ${ }^{28}$ All laccase active fractions were combined and concentrated by Amicon concentrator cell model 8200 and then by model- 3 to $5 \mathrm{~mL}$. The enzyme was stored in a refrigerator in $10 \mathrm{mM}$ sodium acetate/acetic acid buffer of $\mathrm{pH} 4.5$. The enzyme does not lose any activity for 1 month under these conditions.

\section{$2.5 S D S-P A G E$}

Purity of the enzyme preparation was checked by using sodium dodecyl sulphate-polyacrylamide gel electrophoresis (SDS-PAGE). ${ }^{29}$ The resolving gel was $12 \%$ acrylamide in tris/ $\mathrm{HCl}$ buffer $(\mathrm{pH} 8.8)$ and the staking gel was 5\% acrylamide in tris/ $\mathrm{HCl}$ buffer ( $\mathrm{pH} 6.8$ ). The molecular weight markers were phosphorylase
(97.4 kDa), bovine serum albumin $(66.0 \mathrm{kDa})$, ovalbumin $(43.0 \mathrm{kDa})$, carbonic anhydrase $(29.0 \mathrm{kDa})$, soyabean trypsin inhibitor $(20.1 \mathrm{kDa})$ and lysozyme $(14.3 \mathrm{kDa})$. Gel was run at a constant current of $20 \mathrm{~mA} .{ }^{30}$ Molecular weight was determined by Weber and Osborn method. ${ }^{31}$

\subsection{Native-PAGE and zymogram}

Native polyacrylamide gel electrophoresis (PAGE) of the purified enzyme was done using the reported method. ${ }^{32}$ Composition of resolving and stacking gel was similar to that used in SDS-PAGE except that SDS was absent. Reference protein was bovine serum albu$\min 66 \mathrm{kDa}$. Two sets of native gel were done. One set was stained with Coomassie Brilliant Blue R-250 and the other set was used for zymogram ${ }^{33}$ preparation. For the preparation of zymogram, $100 \mathrm{mM}$ DMP solution was made in $10 \mathrm{mM}$ sodium accetate buffer ( $\mathrm{pH} 4.5)$. The native gel was dipped in zymogram solution for 5 min and a brown band appeared. The zymogramgel was removed from the DMP solution and washed thrice with $10 \mathrm{mM}$ sodium acetate buffer $(\mathrm{pH} 4.5)$ at an interval of $5 \mathrm{~min}$.

\subsection{Steady state enzyme kinetics}

Steady state enzyme kinetics of the purified laccase was studied using DMP, ABTS, and syringaldazine as the substrates following methods mentioned in the assay section. ${ }^{25-27} K_{\mathrm{m}}$ and $k_{\text {cat }}$ values for the enzyme were determined from the linear regression of double reciprocal plots. The $\mathrm{pH}$ and temperature optima of the enzyme were determined by measuring the steady state velocities of the enzyme-catalysed reaction in the solutions of varying $\mathrm{pH} /$ temperature keeping the other parameter fixed and drawing graphs of steady state velocities versus the variable parameter. All the data points of the steady state velocity measurements were the average of the triplicate measurements with standard deviations less than $5 \%$.

\subsection{Thermal stability}

Thermal stability of the enzyme was tested by incubating an enzyme aliquot at a particular temperature for $60 \mathrm{~min}$, assaying its residual activity and plotting the residual activity against temperature. For thermal denaturation of the enzyme, rate constants at different temperatures were determined by keeping the enzyme aliquots at different fixed temperatures and assaying the enzyme activity at regular time intervals and plotting 
residual activity against time. Rate constants were calculated from $t_{1 / 2}$ values using equation $k=0.693 / t_{1 / 2}$. Energy of activation for thermal denaturation was calculated by Arrhenius plot.

\section{9 pH stability}

$\mathrm{pH}$ stability of the enzyme was tested by incubating an enzyme aliquot at a particular $\mathrm{pH}$ for $60 \mathrm{~min}$, assaying its residual activity and plotting the residual activity against $\mathrm{pH}$.

\subsection{Biotransformation in the absence of mediators}

Biotransformation of toluene to benzaldehyde ${ }^{22,23}$ was done in $15 \mathrm{~mL}$ of $100 \mathrm{mM}$ sodium acetate buffer (pH 4.5) containing $20 \mathrm{mM}$ toluene in $20 \mathrm{~mL}$ of dioxane and $60 \mu \mathrm{g}$ of purified laccase kept in a $100 \mathrm{~mL}$ conical flask which was stirred vigorously for $1 \mathrm{~h}$. The reaction solution was extracted thrice with $40 \mathrm{~mL}$ of ethyl acetate; $20 \mu \mathrm{L}$ of the ethyl acetate extract was injected in Waters HPLC Model 600E using spherisorb $\mathrm{C}_{18} 5 \mathrm{UV}, 4.5 \times 250 \mathrm{~mm}$ column. The mobile phase was methanol at the flow rate of $0.5 \mathrm{~mL} / \mathrm{min}$. The detection was made using Waters UV detector model 2487 at $\lambda=254 \mathrm{~nm}$. Biotransformations of 3-nitrotoluene to 3-nitrobenzaldehyde and 4-chlorotoluene to 4-chlorobenzaldehyde were also studied using the same method as described earlier.

All the transformed products were confirmed by the analysis of IR and ${ }^{1} \mathrm{H}$ NMR spectra of products.

\section{Results and discussion}

Figure 1(a) shows the secretion of laccase in the liquid culture growth medium amended with various lignincontaining natural substrates such as corn cob, coir dust, saw dust, wheat straw and bagasse particles and inoculated with $C$. floccosa MTCC-1177. The control experiment has similar medium composition except that the lignin-containing natural substrate was absent. It is obvious from the figure that lignin-containing natural substrates when present in the liquid culture growth medium enhanced the secretion of laccase. This enhancement of extracellular secretion of laccase is maximum in the case of the growth medium containing bagasse particles. In order to optimize the secretion of laccase in the presence of bagasse particles, secretion of laccase in presence of different amounts of bagasse particles were studied. The results are shown in figure 1(b). Maximum level of laccase was secreted in the liquid
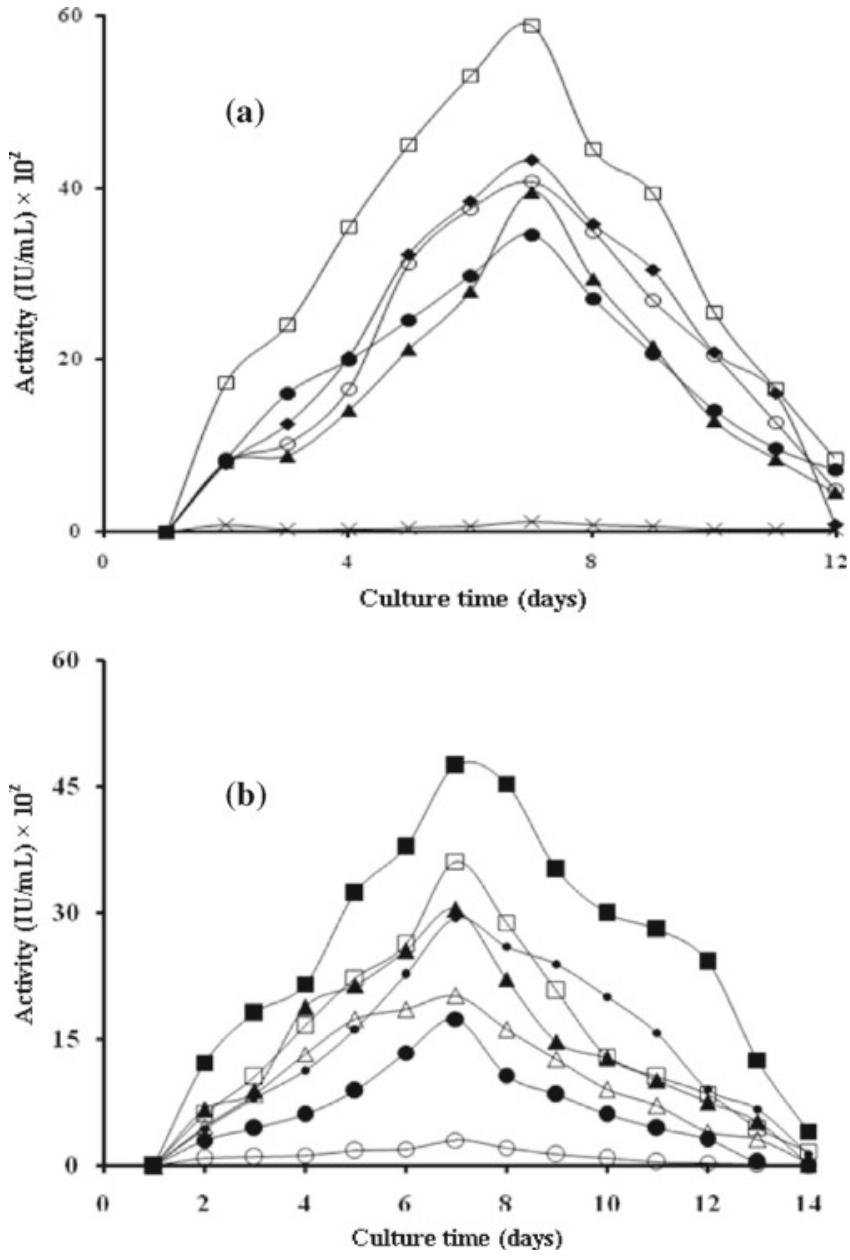

Figure 1. (a) Secretion of laccase by Coriolopsis floccosa MTCC-1177 in liquid culture growth medium supplemented with different natural lignin-containing substrates: wheat straw (@), corn cob $(\bigcirc)$, bagasse $(\square)$, saw dust $(\boldsymbol{\Lambda})$, coir dust $(\mathbf{\square})$, control $(\times)$. (b) Optimization of laccase secretion by $C$. floccosa MTCC-1177 in liquid culture medium supplemented with different amounts of baggase particle $80 \mathrm{mg}(\bigcirc), 100 \mathrm{mg}(\boldsymbol{\Delta}), 200 \mathrm{mg}(\boldsymbol{\square}), 500 \mathrm{mg}(\square), 700 \mathrm{mg}(\bullet)$, $800 \mathrm{mg}(\Delta), 1000 \mathrm{mg}(\mathbf{})$. (The lines are only for connecting the symbols.)

culture medium containing $200 \mathrm{mg}$ of bagasse particles per $25 \mathrm{~mL}$ of culture medium.

Purification procedure of laccase from the liquid culture filtrate of $C$. floccosa MTCC-1177 is summarized in table 1 and the elution profile of laccase activity from DEAE cellulose column is shown in figure 2. The enzyme bound to DEAE cellulose in $10 \mathrm{mM}$ sodium acetate/acetic acid buffer $(\mathrm{pH} 4.5)$ and was eluted by the linear gradient of $\mathrm{NaCl}$ in the range of 0.16 to $0.70 \mathrm{M}$. The method gave 14.74 -fold purification with $21.80 \%$ recovery of enzyme activity. The concentrated enzyme sample was analysed by SDS-PAGE, native PAGE and zymogram preparation. The results of 
Table 1. Purification chart.

\begin{tabular}{|c|c|c|c|c|c|c|c|c|}
\hline Step & $\begin{array}{c}\text { Total } \\
\text { volume } \\
(\mathrm{mL})\end{array}$ & $\begin{array}{l}\text { Activity } \\
\text { (IU/mL) }\end{array}$ & $\begin{array}{l}\text { Protein } \\
(\mathrm{mg} / \mathrm{mL})\end{array}$ & $\begin{array}{l}\text { Total } \\
\text { activity } \\
\text { (IU) }\end{array}$ & $\begin{array}{c}\text { Total } \\
\text { protein } \\
(\mathrm{mg})\end{array}$ & $\begin{array}{l}\text { Specific } \\
\text { activity } \\
(\mathrm{IU} / \mathrm{mg})\end{array}$ & $\begin{array}{l}\text { Purification } \\
\text { fold }\end{array}$ & $\%$ Yield \\
\hline Culture filtrate & 125 & 0.46 & 1.4 & 57.38 & 175 & 0.33 & 1.00 & 100 \\
\hline $\begin{array}{l}\text { Ammonium sulphate } \\
\text { precipitation }\end{array}$ & 20 & 2.15 & 2.3 & 43.08 & 46 & 0.94 & 2.85 & 75.1 \\
\hline Dialysis & 25 & 1.72 & 1.8 & 43.00 & 45 & 0.96 & 2.91 & 74.9 \\
\hline DEAE cellulose & 5 & 2.50 & 0.3 & 12.47 & 1.5 & 8.33 & 25.24 & 21.8 \\
\hline
\end{tabular}

SDS-PAGE, native PAGE and zymogram preparation are shown in figure 3(a), (b) and (c), respectively. In figure 3(a), lane 1 contains molecular weight markers and lane 2 contains purified enzyme. The appearance of single protein band in SDS-PAGE indicated that the enzyme sample was pure. In figure 3(b), lane 1 contains the reference protein bovine serum albumin $(66.0 \mathrm{kDa})$ and lane 2 contains the purified enzyme. Presence of a single protein band in lane 2 where purified enzyme was applied confirmed the purity of the enzyme. Position of purified enzyme in the zymogram figure 3(c) of native PAGE coincides with position of purified laccase in the native PAGE. Molecular mass of purified laccase determined from the analysis of SDSPAGE $^{29}$ was $64 \mathrm{kDa}$. Lowest molecular mass reported for a fungal laccases from Tricholoma giganteum is $43 \mathrm{kDa}$, whereas the highest molecular mass of a laccase reported for Podospora anserine is $383 \mathrm{kDa}$ in the literature. ${ }^{4}$ Thus, molecular mass of purified laccase is in the range of molecular masses reported for other fungal laccases.

The Michaelis-Menten and double reciprocal plots for the purified enzyme using 2,6-dimethoxyphenol as the substrate are shown in figure 4. Similar plots using

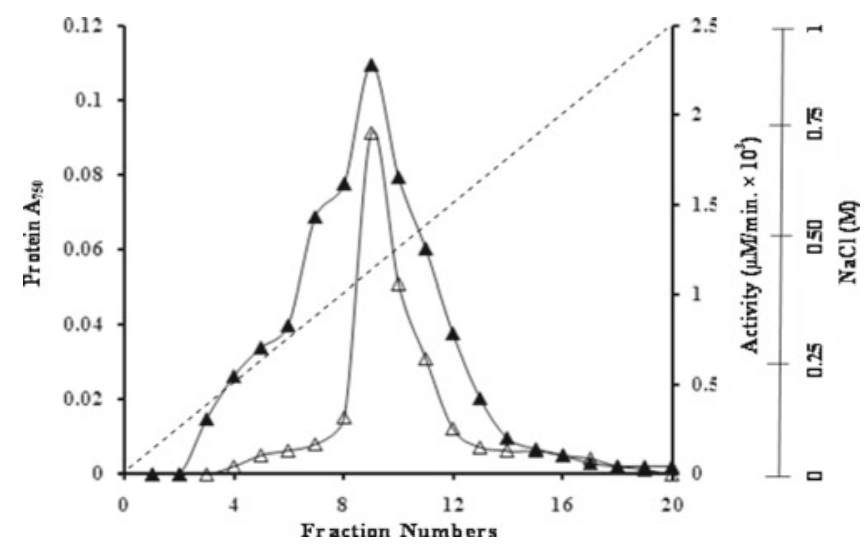

Figure 2. Elution profile of the enzyme from the DEAE cellulose column: Activity $(\boldsymbol{\Delta})$, Protein $(\Delta)$, and $\mathrm{NaCl}(---)$. (The lines are only for connecting the symbols.)
ABTS and syringaldazine as the substrates were also drawn but not given here. The $K_{\mathrm{m}}, k_{\text {cat }}, k_{\text {cat }} / K_{\mathrm{m}}$ and statandard error values determined from the double reciprocal plots using DMP, ABTS and syringaldazine as the substrates are given in table 2. The ranges of $K_{\mathrm{m}}$ values reported ${ }^{4}$ for fungal laccases using DMP, ABTS and syringaldazine as the substrates are $8-14720 \mu \mathrm{M}$, 4-770 $\mu \mathrm{M}$ and 3-3400 $\mu \mathrm{M}$, respectively. However, the $K_{\mathrm{m}}$ value for this laccase for DMP compares well with the $K_{\mathrm{m}}$ of the laccase purified from Rigidoporus lignosus $S .{ }^{4}$ The $K_{\mathrm{m}}$ value of the laccase for ABTS compares well with the $K_{\mathrm{m}}$ of the laccase purified from Agaricus blazei. ${ }^{4}$ The $K_{\mathrm{m}}$ value of the purified laccase for syringaldazine compares well with the $K_{\mathrm{m}}$ of the laccase purified from Magnaporthe grisea ${ }^{4}$ The value of $k_{\text {cat }}$ determined for the purified laccase has been found to be low in comparison to the values of $k_{\text {cat }}$ reported for other fungal laccases. ${ }^{4}$ It is worth mentioning that catalytic performances of laccases span several orders of magnitude for different substrates and are characteristic for specific proteins. ${ }^{4}$

Results of variation of the activity of purified laccase with variation of $\mathrm{pH}$ of the reaction solution are shown in figure 5(a). The determined $\mathrm{pH}$ optimum of

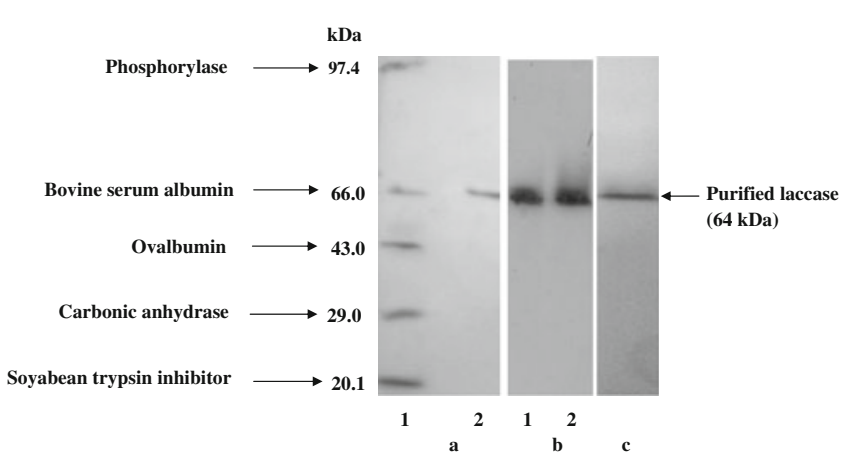

Figure 3. SDS-PAGE (a), native-PAGE (b) and zymogram (c) of the purified laccase: (a) Molecular weight markers (lane 1), purified laccase $5 \mu \mathrm{g}$ (lane 2 ), $R_{\mathrm{f}}$ value 0.43 . (b) Reference protein (lane 1), purified laccase $40 \mu \mathrm{g}$ (lane 2 ), $R_{\mathrm{f}}$ value 0.44 . (c) Pure enzyme stained with DMP. 


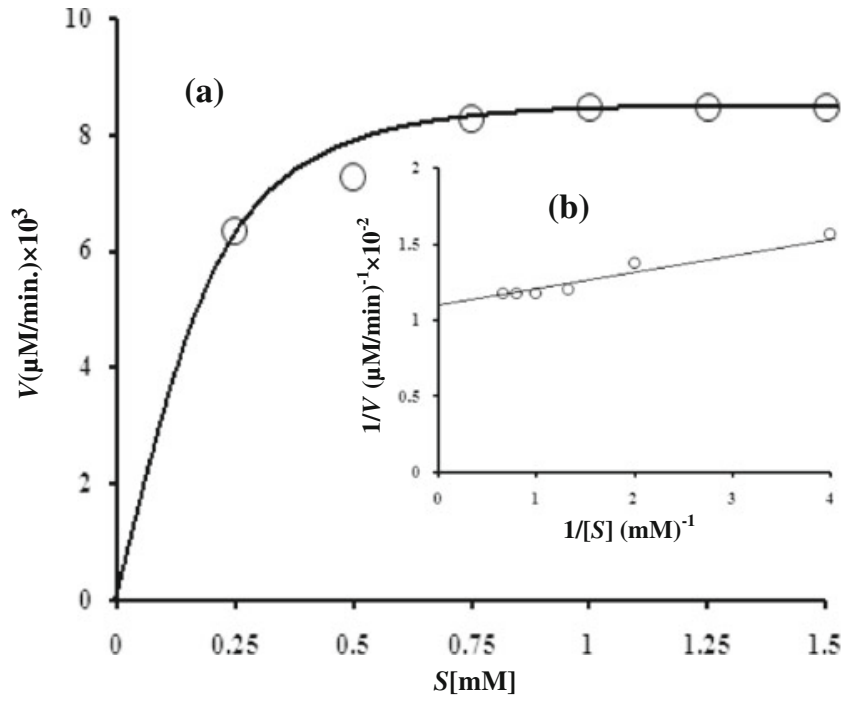

Figure 4. Michaelis-Menten curve (a) and double reciprocal plot (b) for the laccase of Coriolopsis floccosa MTCC1177 using DMP as the variable substrate. In (a) and (b) $1 \mathrm{~mL}$ reaction solution contained $0.0-1.5 \mathrm{mM}$ DMP, $50 \mu \mathrm{L}$ of the enzyme in $100 \mathrm{mM}$ sodium malonate buffer $\mathrm{pH} 4.5$ at $37^{\circ} \mathrm{C}$. (The lines connecting the symbols represent the fits.)

the enzyme was 5.0. The $\mathrm{pH}$ optima reported in the literature $^{4}$ for laccases using DMP as the substrate are in the range $3.0-8.0 \mathrm{pH}$ units. The $\mathrm{pH}$ optimum of the purified laccase compares well with $\mathrm{pH}$ optima of laccases of Chaetomium termophilum and Ophiostoma novoulmi. ${ }^{4}$ The result of studies on $\mathrm{pH}$ stability of laccase are shown in figure 5(b), where activity of the enzyme has been plotted against different $\mathrm{pHs}$ for which the enzyme has been exposed for $1 \mathrm{~h}$. It follows that the enzyme has maximum stability at $\mathrm{pH} 4.0$ under these conditions.

Result of variation of activity of the purified laccase as a result of variation of temperature of the reaction solution of the enzyme-catalysed reaction is shown in figure 6(a). Calculated temperature optimum was $40^{\circ} \mathrm{C}$. The range of temperature optima reported for other laccases are $25^{\circ} \mathrm{C}-80^{\circ} \mathrm{C}$. Temperature optimum of purified laccase compares well with temperature optimum of laccase purified from Lentinula edodes $\mathrm{LCC} 1$ at $40^{\circ} \mathrm{C} .{ }^{4}$

The result of studies on thermal stability of purified laccase is shown in figure 6(b), where residual activities of the enzyme have been plotted against the tempe-

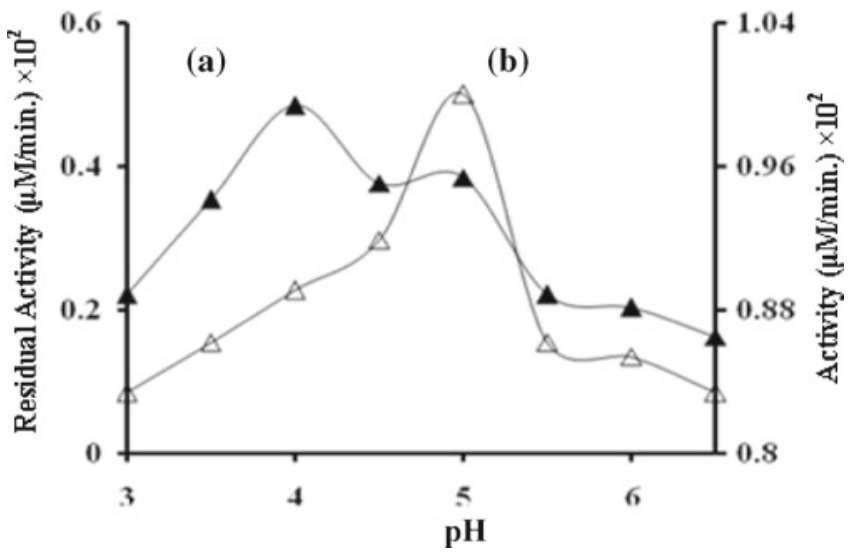

Figure 5. (a) Determination of $\mathrm{pH}$ optimum of the purified enzyme. In case, $1 \mathrm{~mL}$ reaction solution contained $1.0 \mathrm{mM}$ DMP in $100 \mathrm{mM}$ sodium malonate buffer with varying $\mathrm{pH}$ from 3.0 to 6.5. (b) Determination of $\mathrm{pH}$ stability of purified enzyme. In this case, $1 \mathrm{~mL}$ reaction solution contained $1.0 \mathrm{mM}$ DMP in $100 \mathrm{mM}$ sodium malonate buffer with varying $\mathrm{pH}$ from 3.0 to 6.5 and in each case activity is taken after 1 h. (a) $\mathrm{pH}$ optima $(\Delta)$ and (b) $\mathrm{pH}$ stability $(\mathbf{\Delta})$. (The lines are only for connecting the symbols.)

rature at which the enzyme has been exposed for $1 \mathrm{~h}$. The enzyme was most stable at $45^{\circ} \mathrm{C}$. Thermal denaturation curves for different temperatures are given in figure 7(a). Activation energy of thermal denaturation calculated from Arrhenius plot figure 7(b) of purified laccase has been found to be $36.6 \mathrm{~kJ} / \mathrm{mol} / \mathrm{K}$.

Purified laccase does not possess blue colour as visually observed in cases of blue laccases. Instead, it has yellow colour. It has already been reported in the literature ${ }^{17,18}$ that some fungal strains, which secrete blue laccase in submerged liquid cultures, secrete yellow laccases when grown in solid-state fermentation containing natural lignin substrate wheat straw. ${ }^{17}$ Yellow laccases lack absorption band around $610 \mathrm{~nm}$ observed in cases of blue laccases. The UV-Vis spectrum of purified laccase was recorded and is shown in figure 8(a). The authors could not detect the blue absorption band around $610 \mathrm{~nm}$ in the purified laccase spectrum, indicating that it is a yellow laccase. It has also been reported ${ }^{17,18}$ that yellow laccases oxidize non-phenolic substrates in absence of electron transfer mediators which are required in case of blue laccases. Purified laccase also oxidized veratryl alcohol to veratraldehyde in

Table 2. $K_{\mathrm{m}}, k_{\text {cat }}, k_{\text {cat }} / K_{\mathrm{m}}$ and standard error values determined from the double reciprocal plots using DMP, ABTS and syringaldazine as the substrates.

\begin{tabular}{lrcc}
\hline & \multicolumn{1}{c}{$K_{\mathrm{m}}(\mu \mathrm{M})$} & $k_{\text {cat }}\left(\mathrm{s}^{-1}\right)$ & $k_{\text {cat }} / K_{\mathrm{m}}\left(\times 10^{4} \mathrm{M}^{-1} \mathrm{~s}^{-1}\right)$ \\
\hline DMP & $112.50 \pm 3.55$ & $5.16 \pm 0.03$ & $4.60 \pm 0.04$ \\
ABTS & $58.00 \pm 4.00$ & $5.16 \pm 0.04$ & $8.90 \pm 0.04$ \\
Syringaldazine & $100.00 \pm 3.06$ & $5.16 \pm 0.04$ & $5.16 \pm 0.03$ \\
\hline
\end{tabular}




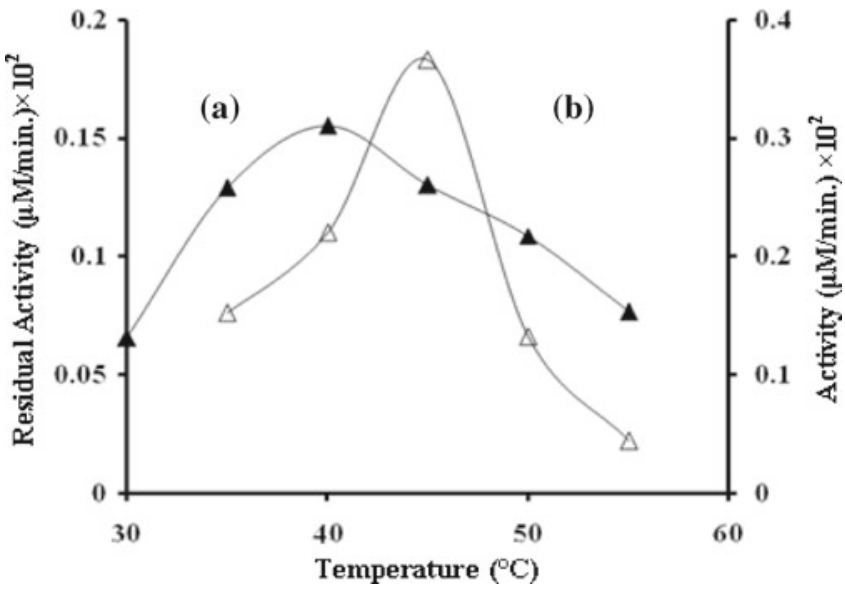

Figure 6. (a) Determination of temperature optimum of the purified enzyme. In this case, $1 \mathrm{~mL}$ reaction solution contained $1.0 \mathrm{mM}$ DMP in $100 \mathrm{mM}$ sodium malonate buffer (pH4.5) with temperature varying from $35^{\circ} \mathrm{C}$ to $55^{\circ} \mathrm{C}$. (b) Determination of thermal stability of purified enzyme. In this case, $1 \mathrm{~mL}$ reaction solution contained $1.0 \mathrm{mM}$ DMP in $100 \mathrm{mM}$ sodium malonate buffer $(\mathrm{pH} 4.5)$ with temperature varying from $40^{\circ} \mathrm{C}$ to $55^{\circ} \mathrm{C}$, and each case activity is taken up after $1 \mathrm{~h}$. (a) Temperature optima $(\boldsymbol{\Delta})$, (b) Thermal stability $(\Delta)$. (The lines are for only connecting the symbols.)

absence of mediator molecules satisfying the property of yellow laccases ${ }^{17,18}$ (figure 8b). However, the reason why copper-containing laccase has yellow colour is not

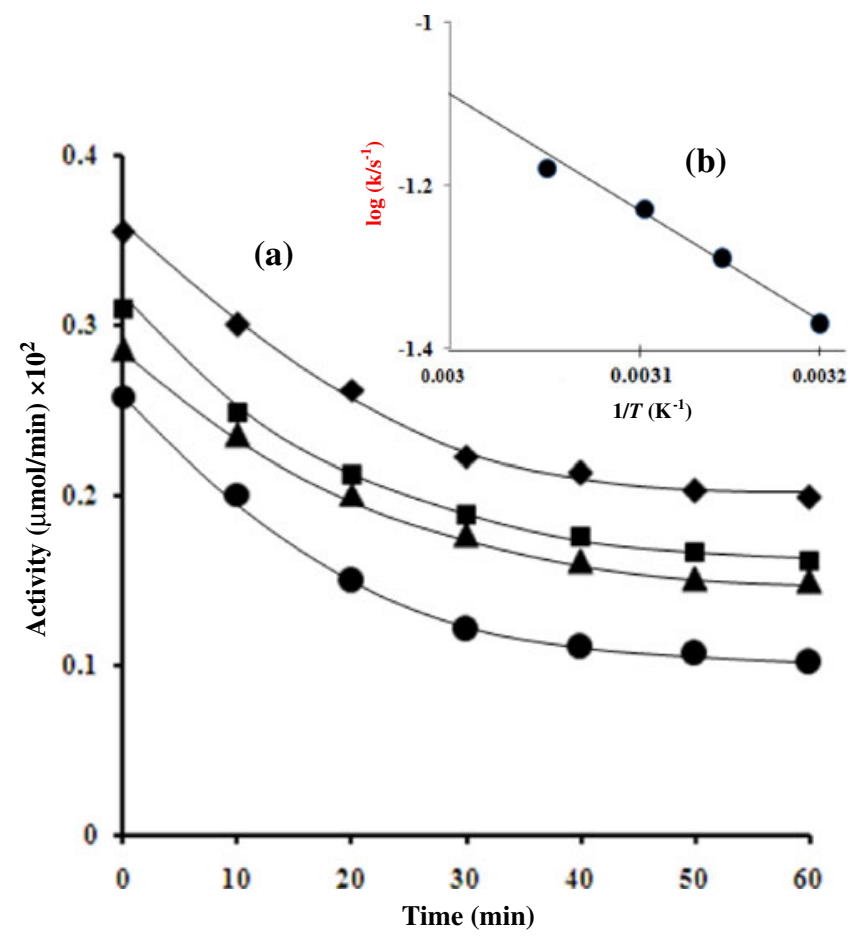

Figure 7. (a) Thermal denaturation of the enzyme at different temperatures. $45^{\circ} \mathrm{C}(\boldsymbol{\diamond}), 50^{\circ} \mathrm{C}(\boldsymbol{\square}), 55^{\circ} \mathrm{C}(\boldsymbol{\Delta})$ and $60^{\circ} \mathrm{C}$ (). (b) Arrhenius plot for the calculation of activation energy of thermal denaturation. (The lines connecting the symbols represent the fits.)

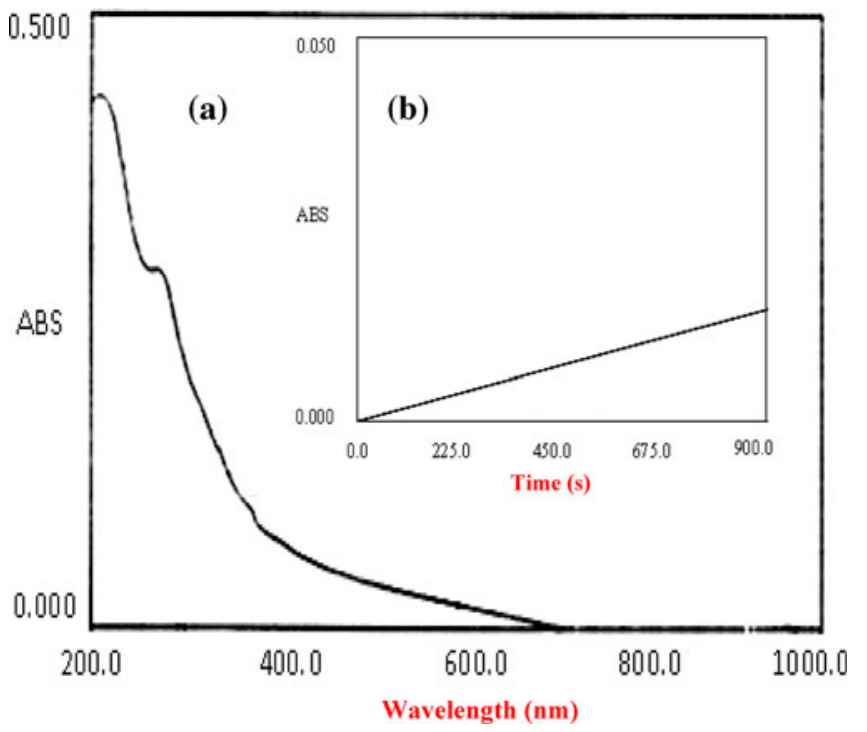

Figure 8. (a) Spectrum of the purified laccase $(4.7 \mu \mathrm{M}$ in $1 \mathrm{~mL}$ in $10 \mathrm{mM}$ sodium acetate/acetic acid buffer ( $\mathrm{pH} 4.5)$ at $30^{\circ} \mathrm{C}$ ). (b) Conversion of veratryl alcohol to veratraldehyde by the purified laccase (increase of absorbance at $310 \mathrm{~nm}$ due to conversion of veratryl alcohol to veratraldehyde with time).

clear at this stage and requires extensive studies which have not been undertaken in this communication.

One of the applications of laccases in organic synthesis is in the selective oxidation of the aromatic methyl group to the corresponding aldehyde. Blue laccases perform this transformation in presence of electron transfer mediator molecules such as ABTS and HOBT; whereas yellow laccases perform this transformation in absence of mediator molecules. The potential of this yellow laccase for transformations of toluene, 3nitrotoluene and 4-chlorortoluene to benzaldehyde, 3nitrobenzaldehyde and 4-chlorobenzaldehyde, respectively, in the absence of mediator molecules was tested. The result in the case of transformation of toluene by the purified enzyme in the absence of mediator molecule is shown in figure 9. Figure 9(a) is the HPLC chromatogram of the ethyl acetate extract of the product formed by the reaction of the enzyme with toluene in the absence of mediator molecule. Figure 9(b) and (c) are the chromatograms of the standard samples of benzaldehyde and toluene, respectively. Retention time of the standard sample of toluene was $2.88 \mathrm{~min}$. and retention time of the standard sample of benzaldehyde was $3.12 \mathrm{~min}$. Thus, retention time of the product of the enzyme-catalysed reaction ( $3.13 \mathrm{~min}$.) coincides with the retention time of the standard sample of benzaldehyde ( $3.12 \mathrm{~min}$.), showing that the product of enzymecatalysed reaction is benzaldehyde. The yield of the product was found to be $93 \%$. Results obtained in 

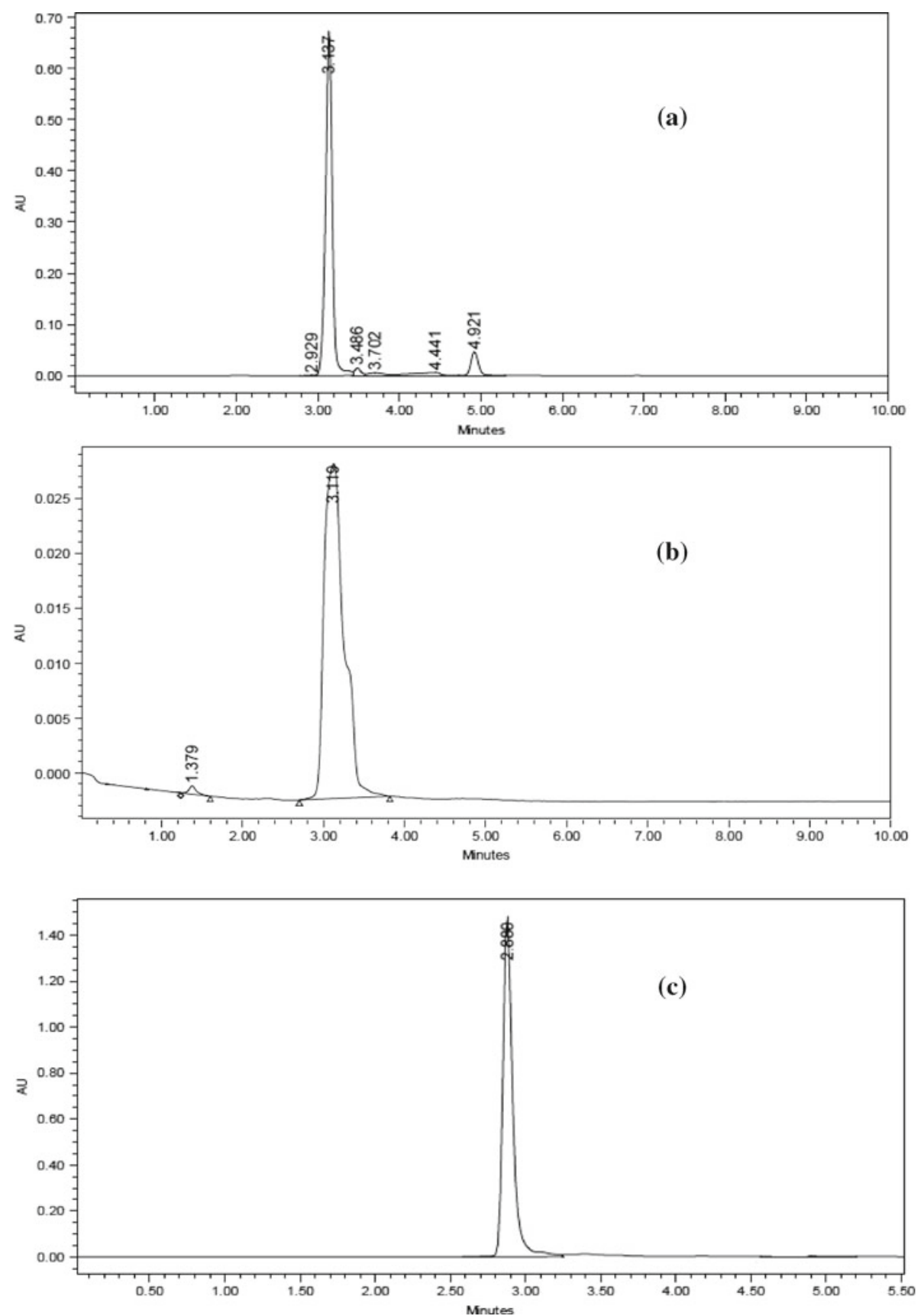

Figure 9. Transformation of toluene to benzaldehyde by the laccase of $C$. floccosa MTCC-1177 in the absence of mediator. (a) Chromatogram of the product of enzymatic reaction with toluene. The reaction solution contained $20 \mathrm{mM}$ of toluene, $20 \mathrm{~mL}$ dioxane, and $15 \mathrm{~mL}$ sodium acetate buffer $(\mathrm{pH} 4.5)$ at room temperature was stirred for $1 \mathrm{~h}$. and extracted thrice with ethyl acetate and $20 \mu \mathrm{L}$ was injected in HPLC. (b) Chromatogram of pure benzaldehyde. (c) Chromatogram of pure toluene.

conversions of 3-nitrotoluene to 3-nitrobenzaldehyde and 4-chlorotoluene to 4-chlorobenzaldehyde were similar. Yields of the products in these cases were found to be $90 \%$ and $87 \%$, respectively.

Identification and characterization of benzaldehyde obtained during the enzymatic reaction was analysed on the basis of IR and ${ }^{1} \mathrm{H}$ NMR spectra results. Since, product is a well-known in literature, the spectra of benzaldehyde is not given here and only results of the spectra have been given. In IR-spectral analysis, band obtained at $v_{\mathrm{C}-\mathrm{H}}=3010 \mathrm{~cm}^{-1}$ is due to the aromatic C$\mathrm{H}$ stretching. Aldehydic $\mathrm{C}-\mathrm{H}$ stretching band appears at $v_{\mathrm{C}-\mathrm{H}}=2760 \mathrm{~cm}^{-1}$, while conjugated aldehydic $\mathrm{C}=\mathrm{O}$ stretching bands appears at $v_{C=\mathrm{O}}=1710 \mathrm{~cm}^{-1}$. A peak at $1340 \mathrm{~cm}^{-1}$ occurs due to aldehydic $\mathrm{C}-\mathrm{H}$ bending. 
${ }^{1} \mathrm{H}$ NMR (300 MHz, ppm) spectral results obtained for the expected product, i.e., benzaldehyde shows a singlet $\delta=9.15 \mathrm{ppm}(1 \mathrm{H})$ due to the aldehydic proton, a doublet $\delta=7.81 \mathrm{ppm}(2 \mathrm{H})$ due to ortho proton, a triplet $\delta=7.39 \mathrm{ppm}(2 \mathrm{H})$ due to meta proton and a triplet $\delta=7.56 \mathrm{ppm}(1 \mathrm{H})$ due to para proton. These above results demonstrate that the product was benzaldehyde.

\section{Conclusion}

In this communication, a laccase from new fungal strain C. floccosa MTCC-1177 has been purified and characterized. The use of the purified enzyme in the selective transformation of aromatic methyl group to aldehyde group in the absence of mediator molecules has been demonstrated.

\section{Acknowledgements}

Financial support by the Department of Science and Technology (DST), Government of India, New Delhi in the form of DST Young Scientist Scheme, to RSSY under which this work has been done, is thankfully acknowledged. AY is thankful to the Department of Chemistry, DDU Gorakhpur University, Gorakhpur, for financial support in the form of UGC-DSA Fellowship for meritorious students, and PKC acknowledges financial support by the Council of Scientific and Industrial Research (CSIR), New-Delhi for the award of JRF. The authors are thankful to Prof. KDS Yadav, Emeritus Scientist, CSIR, New Delhi for helpful discussion.

\section{References}

1. Hoegger P J, Jomes T Y, Kilaru S, Kuees U and Thacker J R 2006 FEBS J. 2732308

2. Messerschmidt A 1997 Multi-copper oxidases (Singapore: World Scientific)

3. Riva S 2006 Trends Biotechnol. 24219

4. Baldrian P 2006 FEMS Microbiol. Rev. 30215

5. Dwivedi U N, Kumar A, Pandey V P and Singh P 2011 J. Mol. Cat. B: Enzymatic 68117

6. Baldwin M J, Lowry M D and Solomon E I 1992 Chem. Rev. 92521

7. Kihumbu D, Liese A and Wandrey C 2000 Org. Proc. Res. Dev. 4285
8. Couto S R and Harrera J L T 2006 Biotechnol. Adv. 24 500

9. Xu F 2005 Ind. Biotechnol. 138

10. Acunzo D F and Galli C 2003 J. Eur. Biochem. 2703634

11. Morozova O V, Shumakovich G P, Shleev S V and Yaropolov Y I 2007 Appl. Biochem. Microbiol. 43523

12. Coniglio A, Galli C and Gentili P 2008 J. Mol. Cat. B: Enzymatic $\mathbf{5 0} 40$

13. Gesell M, Hammer E, Hessel S, Julich W D, Lindoquist U, Lalk M, Mikolasch A, Niedermeyer T H J, Seefeld S, Schauer F and Witt S 2006 Chem. Pharm. Bull. 54632

14. Hammer E, Hessel S, Julich W D, Lalk M, Lindequist U, Mikolasch A, Niedermeyer T H J, Seefeldt S, Schauer F, Salazar M G and Witt S 2007 Chem. Pharm. Bull. 55 412

15. Hammer E, Jonas U, Mikolasch A, Popowski K, Stielo A and Schaner F 2002 Tetrahedron $\mathbf{5 8} 7589$

16. Catalogue of strains-2000 (5th edn), Microbial Type Culture Collection and Gene Bank Institute of Microbial Technology, Chandigarh, p. 60

17. Leontievsky A A, Lankinen P, Myasoedova N M, Pozdnyakova N, Shergill J K and Vares T 1997 FEBS Lett. 1569

18. Golovleva L, Leontievsky A, Myasoedova $\mathrm{N}$ and Pozdnyakova N 1997 FEBS Lett. 413446

19. Osma J, Rodriguez-Couto S and Toca-Herrera J L 2000 Enz. Res. doi: 10.4061/2010/918761, p. 8

20. Brizwani K, Rigdon A and Vadlani P V 2010 Enz. Res. doi: 10.4061/2010/149748, p. 10

21. Desai S S and Nityanand C 2011 Asian J. Biotechnol. 3 98

22. Chen C-L, Gratzl J S, Potthest A and Rosenanu T 1995 J. Org. Chem. 604320

23. Fritz-Langhals and Kunath B 1998 Tetrahedron Lett. 39 5955

24. Sahay R, Yadav R S S and Yadava S 2012 Appl. Biochem. Biotechnol. 166563

25. Coll M P, Fernandez-Abalos J M, Perez P, Somtamaria R and Villomueva J R 1993 Appl. Environ. Microbiol. 59 2607

26. Bourbonnais R and Paice M G 1990 Appl. Microb. Biotechnol. 36823

27. Chefetz B, Chen Y and Hador Y 1998 Appl. Environ. Microbiol. 643175

28. Farrand A L, Lowry O H, Rosebrough N J and Randall R J 1951 J. Biol. Chem. 193265

29. Laemmli U K 1970 Nature 227680

30. Polyacrylamide Gel Electrophoresis 1984 Laboratory Techniques, Pharmacia, Laboratory Separation Division, Uppsala Sweden

31. Osborn M and Weber K 1969 J. Biol. Chem. 2444406

32. Jajow H and Schagger 1991 Anal. Biochem. 199223

33. Zouri-Mechichi H, Mechichi T, Dhouib Sayadi S, Marrtinez A T and Martinez M J 2006 Enz. Microb. Technol. 39141 